\title{
My first employee: an empirical investigation
}

\author{
Alex Coad $\cdot$ Kristian Nielsen $\cdot$ Bram Timmermans
}

Accepted: 24 May 2016/Published online: 30 June 2016

(C) The Author(s) 2016. This article is published with open access at Springerlink.com

\begin{abstract}
The challenge for solo entrepreneurs to add their first employee is arguably the single biggest growth event facing any growing firm. To understand how this event affects performance, and the antecedents of hiring, we analyse Danish matched employer-employee data. Those who hire enjoy superior sales outcomes in subsequent years, while the dispersion in profits increases. Furthermore, those that hire enjoy faster sales growth in the previous year, suggesting that sales growth precedes the first hire.
\end{abstract}

Supporting data are available to bona fide researchers, subject to registration, from Statistics Denmark, at www.dst.dk/en.

\section{A. Coad}

University of Sussex, Falmer, UK

\section{A. Coad $(\bowtie)$}

Knowledge for Growth Unit, Institute for Prospective Technological Studies (IPTS), European Commission, Joint Research Centre (JRC), Edificio Expo. C/Inca Garcilaso 3, 41092 Seville, Spain e-mail: A.Coad@sussex.ac.uk; Alexander.Coad@ec.europa.eu

K. Nielsen - B. Timmermans

Aalborg University, Aalborg, Denmark

B. Timmermans

Agderforskning, Kristiansand, Norway

B. Timmermans

Department of Strategy and Management, Norwegian School of Economics, Helleveien 30, 5045 Bergen, Norway
Finally, we show that founders with a stronger profile in terms of education and previous income are more likely to increase profits, while the characteristics of the employee are less important. The latter finding is important from a job creation perspective, in light of the suggested sorting of more marginalized employees into new and established firms.

Keywords Solo entrepreneurs $\cdot$ Recruitment $\cdot$ Firm growth $\cdot$ Post-entry growth $\cdot$ Scale-up $\cdot$ Employment growth $\cdot$ Sales growth $\cdot$ Founders $\cdot$ New firm growth

Mark Nickel, founder of Sampler Publications, did everything himself for a year. Then he hired the sister of a friend who lived across the street. Her husband had just left her, and she needed to support her kids. His second employee was "a suicidal alcoholic neighbor. I thought I'd rehabilitate her. When she sobered up, I'd let her come over and type names." The third employee was a friend of the second employee. Bhide (2000: 87)

\section{Introduction}

The first hire constitutes the single biggest growth event facing any growing firm-it effectively corresponds to the challenge to solo entrepreneurs to double their workforce. A recent article entitled "Can you afford an employee" from the Danish magazine "The 
Entrepreneur" estimates that the total cost of the first employee is $135 \%$ of the wage paid because of expenses related to payroll system, additional equipment, insurance, social security contributions, additional administration cost, etc., without even taking into account the opportunity cost of the entrepreneur training the first employee (Sand and Paaske 2010). However, these costs and challenges decrease with additional employees hired. Continuing in the Danish context, only around one-third of the new ventures registered in 2013 had employees. In addition, if all 153,364 firms without employees in 2013 took on one additional employee, this would solve the unemployment problem $(153,110$ individuals were registered as full-time unemployed in 2013). Although this statement is rather simplistic as not all unemployed are employable and there may be insufficient demand for firms' output, it remains that self-employed individuals have considerable job-creating potential. Also, once they overcome the hurdle of recruitment and selection, subsequent growth will be easier, and they will develop a taste for further growth (Delmar and Wiklund 2008). Besides performance effects, empirical research has also identified well-being effects for entrepreneurs associated with recruitment, as the life satisfaction of self-employed with employees is found to be higher than those who are self-employed without employees (Blanchflower 2004). Nevertheless, solo entrepreneurs who seek to take on their first employee also face great uncertainty as well as the daunting prospect of trusting someone else with their "baby" (Gartner 1997). Furthermore, it is possible that solo entrepreneurs underestimate the relative abilities of candidate employees, by overestimating their own (a phenomenon known as "illusory superiority"), ${ }^{1}$ and for

\footnotetext{
1 Theoretical work in social psychology has identified the phenomenon of "illusory superiority", which proposes that individuals display systematic cognitive biases in the sense of being overconfident about their abilities when comparing themselves with others (Camerer and Lovallo 1999). One classic example is a nationwide survey of high school students, where $85 \%$ reported they were above the average in ability to get along with others [College Board 1976-1977, cited in Krizan and Suls (2008)]. The social psychology literature has provided plenty of empirical support for illusory superiority (e.g. Hoorens 1993). The flip-side of this cognitive bias is that individuals may wrongly consider the abilities of others to be lower than average. This makes them underestimate the gains to hiring a new employee. Although the benefits of hiring of a first employee may be systematically underestimated, our results may help to correct for this systematic cognitive bias, if we can demonstrate that those solo self-employed that take on their first employee
}

that reason, decide not to hire. Even if they are willing to make their first recruitment, capital restriction, inexperience in hiring and the uncertainty of the future of the venture could make it impossible to attract qualified employees.

Given the challenges of the first recruitment, this paper focusses on this first hire, i.e. the microfoundations of firm growth. Arguably, the first hire epitomizes the distinction between the entrepreneurial and the non-entrepreneurial business. Although we are not the first to investigate the hiring of the first employee (see Carroll et al. 2000; Burke et al. 2000, 2002; Cowling et al. 2004; Henley 2005; Andersson and Wadensjo 2007; Mathur 2010; Congregado et al. 2010; Millan et al. 2013), we contribute to the literature in a number of ways. First, we move beyond the institutional factors that promote the hire decision of entrepreneurs, i.e. low taxes (Carroll et al. 2000), lower health insurance (Mathur 2010) and lower employment protection legislation (Millan et al. 2013), as well as previous work on the overall new venture performance (Congregado et al. 2010), by identifying a range of characteristics of the hiring entrepreneur. In this dimension, we add to the existing contributions that have investigated how personal characteristics of the entrepreneur affect their ability to create jobs, e.g. previous labour market status (Andersson and Wadensjo 2007) and experience (Cowling et al. 2004), gender (Burke et al. 2001), entrepreneurship ability (Burke et al. 2000, 2001) and (financial) assets (Burke et al. 2000; Henley 2005). Contrary to these studies, this investigation not only looks at the characteristics of the entrepreneur and the subsequent hiring decision, but also how this hiring decision affects the performance of the new venture. Furthermore, this study also looks more carefully at the characteristics of the first recruit; despite anecdotal evidence, as illustrated by the opening quote, there is no large sample empirical evidence regarding who gets hired and how these hires differ from other workers transitioning into employment.

Thus, specific research questions we would like to address are: what are the performance antecedents and consequences of making the first hire? Which entrepreneurs will hire, and which employees will be

Footnote 1 continued

enjoy favourable outcomes, compared to a suitable control group who remain solo self-employed. 
hired? Our research focus is therefore simultaneously narrow and broad: narrow in that it focuses specifically on the first hire made by solo self-employed entrepreneurs 2 years after entry, and broad because it takes a number of approaches to shed light on different facets of this first hire event. More specifically, we look at the change in new venture performance when adding an employee by investigating growth in sales and profits.

By using a detailed, large-scale database to create a valid comparison between "treatment" and "control" groups, we explore the evolution of the two groups over time and investigate whether sales growth precedes or lags behind employment growth. Moreover, we investigate not only what happens to the firms that hire, but we also take into account the questions "who hires?" and "whom gets hired?" Indeed, if the recruitment challenges of entrepreneurs hold, we would expect to see entrepreneurs with more verifiable human capital to be more likely to attract (qualified) employees, and a selection of less qualified employees into the new ventures compared to incumbent firms.

Our matching estimators show that those who hire enjoy superior sales outcomes in subsequent years, while the dispersion in profits increases. Analysis of the evolution of sales growth around the time of the first hire reveals that those entrepreneurs that hire enjoy faster sales growth in the previous year, suggesting that sales growth precedes the first hire. This important finding suggests that not all solo entrepreneurs should hire-only those with sufficient sales growth to justify the workforce expansion. The first employee then boosts sales growth in subsequent years. Turning to the questions of "who hires?" and "whom gets hired?", regressions show that the likelihood of recruiting the first employee increases with education and opportunity-based start-up. Moreover, those that get hired in the new ventures (compared to those hired by incumbents) are more likely to be less educated and also unemployed (or employed with a lower income) the year before being hired. Finally, we show that founders with a stronger profile in terms of education and previous income are more likely to increase profits, while the characteristics of the employee are less important. Together, these findings emphasize the positive job-creating function of entrepreneurs for society and the need to address the possible barriers for the majority of solo entrepreneurs of taking on their first employee, as well as including an additional dimension to the debate regarding which entrepreneurs to promote and support through policy.

The next section describes the theory related to hiring the first employee followed by the methodology behind this quantitative study. The empirical results are presented and discussed at the end with limitations and policy implications.

\section{Theory and hypotheses}

The section derives hypotheses related to the questions "what happens when solo entrepreneurs hire?", "who hires?" and "whom gets hired?" by reviewing the literature concerning co-evolution of firm growth and recruitment, the benefits of recruitment and the challenges of recruitment.

\subsection{Co-evolution of firm growth and recruitment}

Firm growth is a multifaceted phenomenon, because employment growth and sales growth are distinct (but coevolving) dimensions of growth that shed light on different aspects of the growth process (Shepherd and Wiklund 2009; Miller et al. 2013). However, after having recognized that these two dimensions of growth are distinct, the question then turns to whether one precedes the other (Coad 2010; Achtenhagen et al. 2010). Which comes first: sales growth or employment growth?

There are arguments for both causal directions. On the one hand, hiring might lead to further sales growth because of the simplistic logic that employment is an input, while sales is an output (but this in itself doesn't stop sales from preceding employment), and also because employment growth boosts sales through the drawing up of subsequent growth projects (Penrose 1959 on large firms). Firms might thus decide to scale up by hiring more employees to better pursue business opportunities (Coad and Guenther 2014).

On the other hand, sales growth might engender a subsequent increase in the workforce. In this view, firms hire to respond to overwhelming demand and to ease the strains on their overstretched workers. Indeed, the empirical evidence points this way: Moneta et al. (2013) analyse the growth processes of large US firms and observe that sales growth comes first in the causal ordering of growth variables, before employment growth. 
In our present research context, we emphasize that the first hire is an especially daunting growth event that effectively corresponds to a sudden doubling of the workforce. The first hire brings about many challenges relating to work organization (e.g. reconfiguration of tasks and redesigning of routines, issues of monitoring and moral hazard, communication and coordination), such that we expect that solo entrepreneurs will be risk-averse and reluctant to make their first hire until they are overwhelmed with increases in sales. Therefore, we suggest that:

H1 Entrepreneurs who make their first hire will have higher sales growth in the preceding period than entrepreneurs who do not hire.

\subsection{Benefits of recruitment}

There are strong arguments that hiring additional employees provides access to additional resources and enables scale increases. These factors allow entrepreneurs to better deal with environmental uncertainties (Shane 2003; David and Watts 2008; Sarasvathy 2008), and they are critical to the success of new and small businesses (Hornsby and Kuratko 1990; Deshpande and Golhar 1994; Cardon and Stevens 2004). ${ }^{2}$ Not being able to attract the necessary human resources is also recognized to be detrimental to the survival of the business (Katz et al. 2000; Leung et al. 2006), and it is also among the most cited threats to business growth (Williamson et al. 2002; Lee 2014). Empirical evidence confirms that new ventures with more employees outperform other new ventures taking into consideration a broad range of performance indicators like survival, growth, profitability and initial public offering (Shane 2003, p. 239; Coad et al. 2014).

In addition, research shows that life satisfaction of the self-employed is on average higher than the life satisfaction of employees; nonetheless, the life satisfaction of the self-employed with employees is even higher (Blanchflower 2004, p. 54). Furthermore, Tamvada (2010) observes that employing entrepreneurs have higher earnings (or more specifically, consumption expenditures) than solo entrepreneurs.

\footnotetext{
${ }^{2}$ Earlier work on the recruitment and selection focused predominantly on the practices of small firms rather than new ventures per se.
}

More generally, entrepreneurs appear to benefit from recruiting employees in terms of both new venture performance and well-being. Despite the importance and benefits of human resources, recruiting employees is far from an easy task for entrepreneurs as recruitment and selection are affected by a combination of organizational attributes (including characteristics of the entrepreneur), organizational legitimacy and labour market characteristics. In particular, recruiting qualified employees with the desired set of skills and competences is a challenge (Williamson et al. 2002; Aldrich and Ruef 2006).

\subsection{Challenges in recruitment}

Small-sample, case-based studies and surveys have continuously demonstrated that recruitment and recruitment selection practices differ substantially among firms, predominantly the dimension of size (Deshpande and Golhar 1994; Barber et al. 1999; Carroll et al. 1999) but also when it comes to firm age (Cardon and Stevens 2004; Cardon and Tarique 2008). These differences manifest themselves mainly on the use of more formal processes of recruitment like relying on job postings and the use of external recruitment agencies in larger wellestablished firms compared to more informal, ad hoc and idiosyncratic methods (e.g. relying on social networks and recommendations of existing staff) in small firms and young organizations (Carroll et al. 1999; Aldrich and Ruef 2006; Barrett and Mayson 2008); this is beautifully illustrated in the opening quote that precedes our Introduction section. In essence, in their efforts to recruit-or probably more accurately to select ${ }^{3}$ - a candidate, entrepreneurs face challenges associated with their liability of smallness (Aldrich and Auster 1986) and liability of newness (Stinchcombe 1965; Freeman et al. 1983). These two features of new ventures, which are closely related to each other although also distinct, will affect recruitment and selection in different ways (Cardon and Stevens 2004). ${ }^{4}$

\footnotetext{
${ }^{3}$ Contrary to larger or more established firms, entrepreneurs often do not have the luxury to select a candidate from a large pool of applicants. Given its ad hoc nature, most entrepreneurs will be confronted with only one candidate, if any, and the subsequent decision to hire this one individual. This is probably most common when recruiting the first employee.

${ }^{4}$ In addition to organizational features that explain difficulties in recruitment, other (institutional) obstacles might affect entrepreneurs that are interested in making their first hire for
} 
Liability of smallness can be associated with organizational awareness and resource constraints. Organizational awareness affects entrepreneurs in two ways (Williamson et al. 2002). First, it affects them as job seekers cannot be attracted to apply for a position at a firm they are not familiar with, i.e. they lack organizational familiarity. Second, even if the job seeker is familiar with the organization it is more difficult to acquire credible information about the organization and the organization's image. Resource constraints will set limits to the ability of entrepreneurs to invest in a formal recruitment process to identify (qualified) employees beyond the immediate network, to advertise the new venture to counter the above-mentioned organizational awareness, and the ability to offer attractive wages and other employee benefits (e.g. on the job training) to potential candidates (Leung 2003; Aldrich and Ruef 2006). In addition to lacking organizational awareness and resource constraints, new ventures are confronted with a relative unfamiliar environment and lack a track record of performance (Cardon and Stevens 2004); consequently, clearly defined organizational roles and overall organizational legitimacy, which can be gathered under the heading of liability of newness, have not been established. Due to their inexperience with hiring employees, these entrepreneurs cannot provide this labour market signal; in addition, there are no individuals that have filled this job position previously compared to established firms in the industry (Aldrich and Ruef 2006). So even if these new ventures are known by the job seeker and do not suffer from resource constraints as such, job seekers are not able to assess whether the entrepreneur is a desirable or attractive employer (Williamson et al. 2002).

\subsubsection{Who hires?}

Informal recruitment methods can alleviate some of the problems of liability. First, by using direct and indirect ties, the cost of recruitment and the following monitoring of the worker decreases. In addition, the informal nature of the search process provides better

Footnote 4 continued

example national regulations such as employment protection regulation (Millan et al. 2013) and health insurance regulations (Mathur 2010). Given the one-country setting of this study, we do not elaborate on this any further. opportunity for the entrepreneur to obtain knowledge about the competencies of the potential employee, and for the potential employee to obtain more organizational knowledge and more information on the role he or she might play in the new venture, and an assessment on whether the entrepreneur could potentially be a good reliable employer (Aldrich and Ruef 2006). Thus, it may reduce uncertainty in the employment relationship. This last factor is potentially important, as the ability for an entrepreneur to attract quality employees would, just as in any other form of resource acquisition (Shane 2003), be dependent on the quality of the entrepreneur. Higher-quality entrepreneurs, or entrepreneurs that can signal high quality (e.g. based on education and previous entrepreneurial and work experience), are expected to attract betterquality employees into the organization (Bublitz et al. 2015). The fact that a new venture survives the initial phases also has a signalling value; consequently, as demonstrated by Andersson and Wadensjo (2007), "the probability of having employees increases with time spent in self-employment" (Andersson and Wadensjo 2007, p. 616).

From this discussion, we derive the following hypothesis:

H2 More qualified entrepreneurs can send stronger signals to potential applicants and are more likely to hire.

\subsubsection{Whom gets hired?}

In addition to answering the question who hires, it is also relevant to discussing what characterizes the candidates entrepreneurs hire. One has to consider that the majority of potential employees are already employed, and those that are not, or those who are seeking new job opportunities, have the opportunity to select among — or are directly approached by—a large set of other (established) organizations that are able to provide well-paid and well-defined job positions, in particular if these individuals are highly qualified. Thus, in the process of selecting employees, the entrepreneur is exposed to asymmetric information, adverse selection, moral hazard and uncertainty (Shane 2003). Consequently, economists argue job seekers that are attracted to work for new ventures have generally limited outside options or are in other ways marginalized on the labour market, e.g. 
unemployed, difficulties holding a steady job (Bhide 2000). Furthermore, given their similarity to small organizations, one might follow the argument by Atkinson and Storey (1994) who mentioned that:

[w] ages are lower, training is less frequent, and the evidence for a compensating higher level of job satisfaction is weak [contrary to entrepreneurs]. Furthermore, in view of the financial weakness of many small businesses ... and their relatively low levels of unionisation, effective job security for workers is likely to be lower than for workers in large firms (p: 11, text in brackets added).

It is therefore not surprising to observe that when entrepreneurs are able to attract employees, these employees are more likely to be part-time workers, to be less educated, to receive lower wages and benefits, to receive less training, to work longer hours, to be more likely to get injured, to be younger and to have lower job tenure (Parker 2004: p. 197).

Based on this discussion, we derive the following hypothesis:

H3 Entrepreneurs hire workers that are less qualified compared to workers hired in incumbent firms.

\section{Method}

\subsection{Motivation for the chosen methodology}

Interest from researchers and policymakers into the job-creating process has led to a large literature on firm-level employment creation and firm growth (Birch 1979; Haltiwanger et al. 2013); some even claim that growth is "the very essence of entrepreneurship" (Sexton and Smilor 1997: p. 97). However, despite the efforts, research into the determinants of firm growth has been slow (McKelvie and Wiklund 2010), and our ability to predict which firms will grow is hardly better than random (Geroski 2000; Coad et al. 2013; Denrell et al. 2015). Geroski (2000: p. 169) summarizes the literature thus: "The most elementary 'fact' about corporate growth thrown up by econometric work on both large and small firms is that firm size follows a random walk".

Considering the difficulties in explaining how much firms will grow, in this paper we take a different approach, by focusing on a narrowly defined-yet crucially important-growth event. Our novel approach is inspired by some reflections from Nobel Laureate Herbert Simon (1984: p. 40):

In the physical sciences, when errors of measurement and other noise are found to be of the same order of magnitude as the phenomena under study, the response is not to try to squeeze more information out of the data by statistical means; it is instead to find techniques for observing the phenomena at a higher level of resolution.

We therefore focus on a narrowly defined growth event instead of attempting to explain all growth events faced by all firms-we focus on the first hire. Although the usual mantra is that "the more observations the better", in some cases extra precision can be gained in econometric estimates by discarding irrelevant observations that are poor matches. ${ }^{5}$ In our case, we start with the population of Danish start-ups, but then focus on a bounded sample to obtain clean evidence on the first hire event. Even though we discard most of our observations, we nevertheless have a relatively large number of observations remaining - corresponding to all relevant start-ups in Denmark over the period 2001-2006. While having a small number of observations is not a virtue per se, our focus on a homogenous sample-as also suggested in Sarasvathy (2004)—leads us to gain new insights by looking at firm growth "under the microscope".

\subsection{Data and empirical design}

The data used for the main analysis are of a longitudinal matched employer-employee register of all individuals and firms in Denmark [e.g. used in Nanda and Sørensen (2010), Dahl and Sorenson (2012), Coad and Timmermans (2014) and Nielsen (2015); see also Timmermans (2010)]. How this register database differs from other registers is that it is created in close collaboration with academic researchers for the purpose of conducting labour market research. We identify new ventures with only

\footnotetext{
5 This is referred to by Ho et al. (2007: 214) as the paradoxical advantage of matching estimators that consists of reducing variance by discarding data.
} 
Fig. 1 Entrepreneurs are matched at start-up ("twins" matched at birth), neither hire at $t=2$, and the "treatment" hires one employee (only) at $t=3$, while the "control" hires no one at $t=3.2215$ firms are in "treatment"; 31,082 firms are in "control"

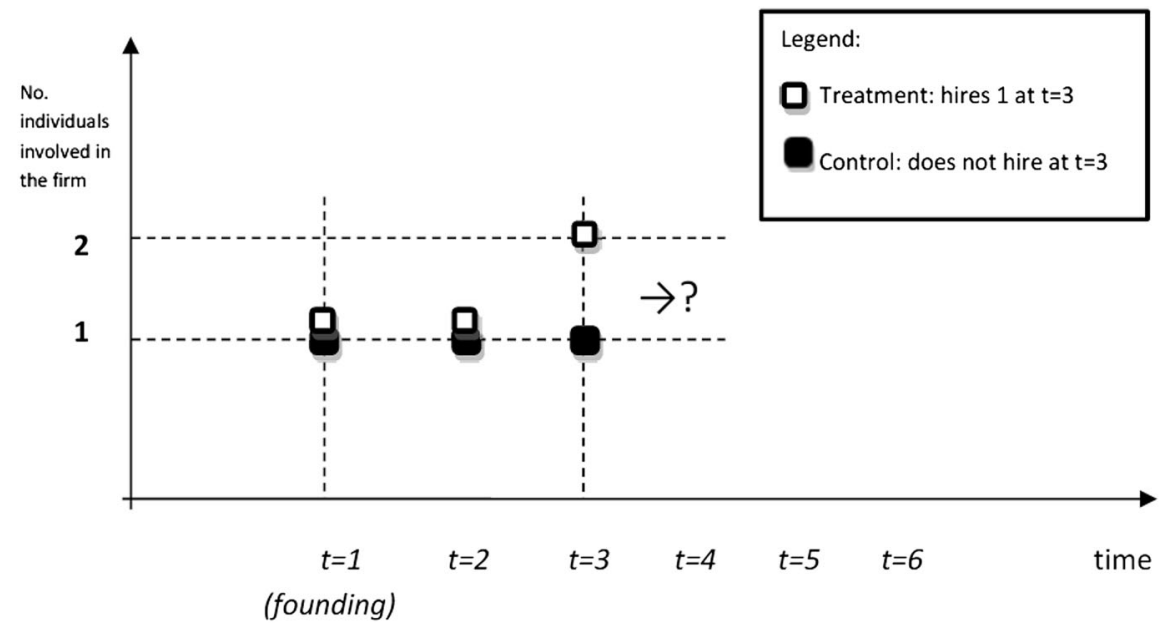

one registered founder in the period 2001-2006. The main analysis is to compare the performance-growth in sales and profits - of start-ups that hire an employee compared to those that do not. More specifically, we observe the solo self-employed start-ups at time $t=1$, ensure that they do not hire in $t=2$ and then distinguish between those that hire one employee in $t=3$ (2215 "treatment" firms) versus those that do not hire an employee in $t=3$ (31,082 "control" firms), resulting in a total sample of 33,297 . We then observe the performance outcomes of firms up to $t=6$. Figure 1 provides a summary representation of our empirical set-up.

The reason why we ensure that founders do not hire anyone at $t=2$ is because we want to include new ventures that have already reached some sort of "steady state" and are accustomed to operating as stand-alone self-employed individuals, instead of having their first hire in mind at the time of founding. ${ }^{6}$ While these data restrictions are strong, nonetheless our narrow sampling strategy provides clean evidence on the impact of the first employee compared to a suitable control group (and moreover, our large-scale national dataset means we have enough observations for meaningful statistical analysis). The empirical

\footnotetext{
${ }^{6}$ Problematic would be the case where an entrepreneur enters in December of 1 year and makes the first hire in January of the following year-we are not interested in such observations, because it is likely that the entrepreneur had the first hire in mind already at the time of founding.
}

design in the different analyses investigating "what happens happen when solo entrepreneurs hire?", "who hires?" and "whom gets hired?", respectively, is outlined next.

Semi-parametric matching estimators and a carefully selected control group allay endogeneity concerns in estimating the causal effect of the first recruitment on subsequent firm performance. In analogy to the "twin studies" experimental design (Boomsma et al. 2002), firms are matched at birth (although the "twins" may randomly have different experiences between birth and the treatment opportunity) and we observe how an event in later years $(t=3)$ impacts on their overall development. Matching is based on initial sales, initial profits, gender, age, immigrant status, marital status, education level (i.e. at least a college degree), labour market status the year before start-up (employed, unemployed, outside of the labour force or under education), income in year before start-up, household wealth in year before startup, parental entrepreneurship experience, industry dummies and region dummies. In addition, these personal matching variables are used as explanatory variables in estimating the characteristics of those entrepreneurs that hire an employee (2214 individuals behind 2215 new firms) compared to those that do not hire (30,513 individuals behind 31,082 new firms) in a logit model. In the same way, the personal matching variables are used to estimate the characteristics of those that get hired in the 2215 new ventures compared to a control group of 12,000 randomly selected individuals that were hired in the same period (2000 
individuals from each of the years 2003 to 2008) in established firms in the private sector founded before 1991, i.e. firms that are at least 10 years old; the control group consists of 11,961 different individuals hired in 5235 different firms. Finally, the personal characteristics of the founders as well as the employees in the 2215 hiring firms are used as explanatory variables in logit models with the top third (1) and bottom third (0) percentile regarding profits 5 years after start-up (3 years after hiring the first employee) as dependent variable. Descriptive statistics on the population containing the treatment and control group can be seen in "Appendix" (Tables 6, 7, 8; see also Table 9 for a correlation matrix).

Although our empirical set-up was designed to shed light on the causal effects of sales growth and employment growth around the time of the first hire, nevertheless caution should be used before interpreting our estimates as causal effects. There may be unobserved differences between the treatment and control groups at the time of birth, that cannot be detected using observed variables (often referred to as "unconfoundedness" or "selection on observables", see, for example, Imbens and Wooldridge 2009). ${ }^{7}$ Considering that the treatment is not externally imposed, but that it is a choice made by the entrepreneurs, there may remain self-selection bias into the treatment/control groups, despite our best efforts to control for differences using observed variables as controls.

In addition to the matching analysis, we further investigate the phenomenon of the first hire by performing standard regressions to uncover the characteristics of which entrepreneurs hire and which individuals get hired, and business-level outcomes (in terms of profits) that occur after the first hire. These are presented in Sects. 4.2 and 4.3.

\footnotetext{
$\overline{7}$ One such problematic omitted variable could be growth aspirations at the time of birth. In this case, it could be the anticipation of future sales growth that "causes" employment growth, even if employment growth is observed before any change in realized sales. However, given the prevalence of overoptimism affecting entrepreneurs' forecasts (Hayward et al. 2006), the difficulties in forecasting and the time lags used in our empirical design (no one hires until the third year), we consider this problem to be relatively minor.
}

\section{Analysis}

We begin by describing the evolution of sales and profits around the time of the first hire, using a graphical analysis (using boxplots) as well as matching estimators that focus on estimating the causal effect of the first hire (Sect. 4.1). Later sections apply multivariate regressions to address in more detail who hires and who gets hired (Sect. 4.2) and the determinants of post-hire profits (Sect. 4.3).

\subsection{Matching estimates of the treatment effect of the first hire}

We begin by inspecting boxplots (see Fig. 2) of the evolution of sales and profits for the solo founders that hire their first employee (i.e. the treatment group) compared to those who do not hire (i.e. the control group). A first finding is that, in all years, there is considerable heterogeneity between firms in terms of their sales and profits. Furthermore, given the earlier reported differences between those that hire family members and those who do not, we have made some boxplots where we removed the new ventures where the founder recruited family. We see that sales is higher in the treatment group even 1 year before their first hire (i.e. even in $t=2$ ), which suggests that these firms enjoy sales growth before deciding to hire an employee. Instead of new employees "earning their keep" in terms of boosting sales once they arrive at time $t=3$, Fig. 2 (left) suggests that instead it is sales growth that precedes employment growth.

Figure 2 (right) shows the evolution of profits in the years after entry. "Treatment" firms start off with slightly lower profits at time $t=1$ and have similar profits at $t=2$, and at the time of the first hire onwards ( $t=3$ onwards), treatment firms have slightly larger median profits, but also more dispersion in the distribution of their profits. The first hire, therefore, does not always lead to higher profits, but in a few cases could lead to profits being more strongly negative. ${ }^{8}$

\footnotetext{
$\overline{8}$ Note, however, that if the profits variable is log-transformed, as is frequently done for skewed distributions such as this, then observations of negative profits will all be excluded from the data sample by construction, thus introducing selection bias, and making the profits variable appear to rise over time.
} 

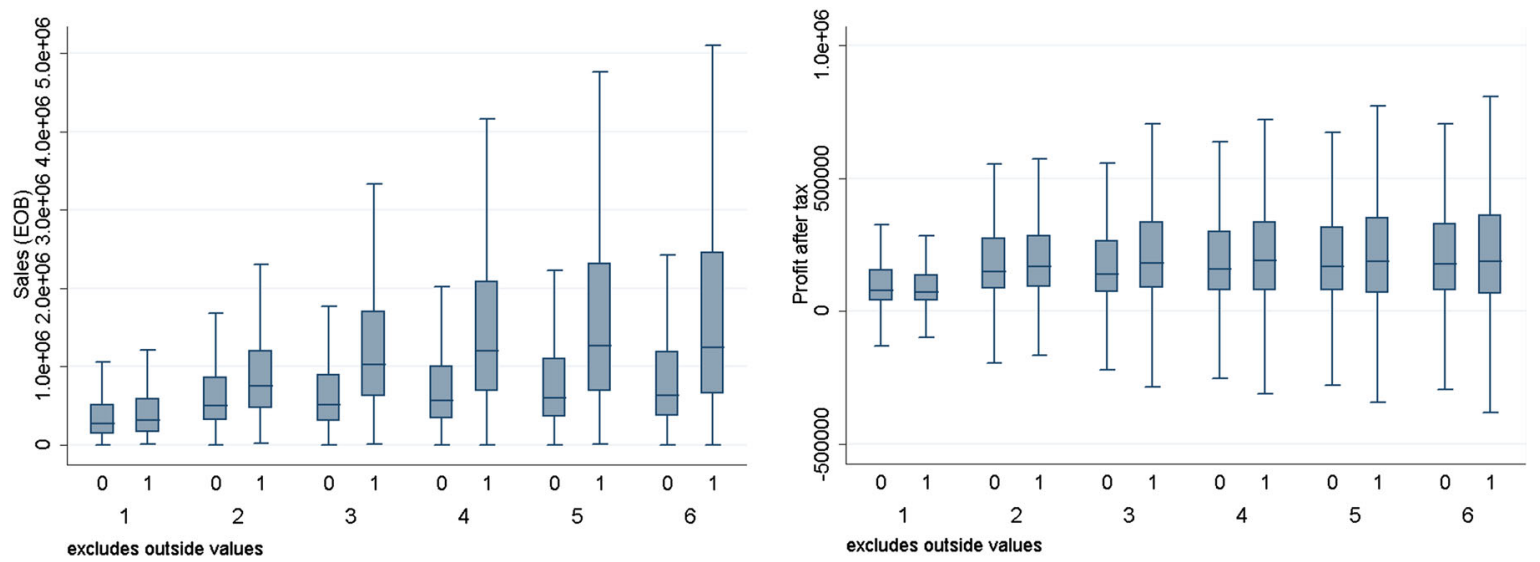

Fig. 2 Boxplots for the evolution of sales (left) and profits (right), for the 6 years since start-up, for treatment (1) and control (0)

Figure 3 in "Appendix" provides an alternative representation of Fig. 2, when the variables sales and profits are log-transformed. Taking logarithms has the advantage of compressing the range, although it requires that only positive values can be included in the calculations, which is problematic for our profits variable.

Turning to the main analysis of the study, we apply propensity score matching. ${ }^{9}$ The matching estimates in Table 1 reveal that those who hire an employee enjoy superior outcomes (sales and profits) in the years after the hire.

The first of the three panels in Table 1 corresponds to $\log$ sales as the outcome variable. ${ }^{10}$ In the year of founding $(t=1)$, there are no significant differences between treatment and control. From $t=2$ onwards, however, the treatment group has larger sales than the control group. The difference between the two increases from $t=2$ to $t=4$ and, after reaching a maximum, then decreases slightly over the period $t=4$ to $t=6$. It is interesting to observe that those that hire in $t=3$ enjoy faster sales growth in the previous year $(t=2)$, suggesting that sales growth precedes the first hire. This novel and important finding suggests that not all entrepreneurs can hire their first employee-only those with sufficient sales growth to justify the workforce expansion. The first employee

\footnotetext{
9 We also sought to complement our results with multidimensional nearest-neighbour matching (Abadie et al. 2004), but problems with the computations meant that this estimator was not able to yield any results.

10 Since sales takes non-negative values, we log-transform this variable to normalize it and make it less heavily skewed.
}

then boosts sales growth in subsequent years. This has important implications for encouraging entrepreneurs to hire their first employee-not all entrepreneurs should do so, because sales growth seems to precede employment growth in the causal ordering of firm growth processes (Moneta et al. 2013).

The second of the three panels in Table 1 reports ATT estimates for $\log$ (profits). These results mirror those found for $\log$ (sales), because from $t=2$ to $t=5$ the treatment group enjoys higher profits than the control group who do not hire, with the largest difference occurring in the year of the first hire at $t=3$. The results show similar patterns when excluding those observations where the first hire is a family member. Keeping in mind, however, that log-transforming the profits variable introduces bias into our estimates, all cases of negative profits are dropped. Therefore, the third of the three panels in Table 1 corresponds to profits as the outcome variable. Here we see that the treatment and control groups never have a significant difference between them in any of the years considered. Taken together, the second and third panels of Table 1 highlight how firms that hire can be shown to enjoy higher profits if the negative cases are excluded, while when we include the full sample there is no difference between those that hire and those that don't. The first hire is a double-edged sword that can lead to higher profits or higher lossesbecause it results in more dispersion in profits. Hence, it is natural to ask whether the characteristics of who hires and who gets hired as previously assessed are important for the likelihood of success as measured by post-hire profits-to this we now turn. 
Table 1 Matching estimates

\begin{tabular}{|c|c|c|c|c|c|}
\hline Year & Treated & Controls & Difference & SE & $t$ stat. \\
\hline \multicolumn{6}{|c|}{ Log(sales) } \\
\hline 1 & 12.641 & 12.644 & -0.003 & 0.033 & -0.100 \\
\hline 2 & 13.592 & 13.386 & 0.205 & 0.028 & 7.370 \\
\hline 3 & 13.873 & 13.357 & 0.517 & 0.029 & 17.930 \\
\hline 4 & 14.014 & 13.467 & 0.547 & 0.031 & 17.850 \\
\hline 5 & 14.071 & 13.611 & 0.460 & 0.035 & 13.150 \\
\hline 6 & 14.098 & 13.674 & 0.423 & 0.038 & 11.160 \\
\hline \multicolumn{6}{|c|}{$\log$ (profits) } \\
\hline 1 & 11.194 & 11.179 & 0.015 & 0.034 & 0.450 \\
\hline 2 & 12.010 & 11.890 & 0.120 & 0.032 & 3.750 \\
\hline 3 & 12.137 & 11.833 & 0.304 & 0.035 & 8.810 \\
\hline 4 & 12.170 & 11.964 & 0.206 & 0.036 & 5.650 \\
\hline 5 & 12.155 & 12.041 & 0.114 & 0.042 & 2.690 \\
\hline 6 & 12.193 & 12.109 & 0.085 & 0.046 & 1.830 \\
\hline \multicolumn{6}{|c|}{ Profits } \\
\hline 1 & $128,891.952$ & $142,223.165$ & $-13,331.213$ & $12,599.687$ & -1.060 \\
\hline 2 & $264,008.212$ & $229,775.713$ & $34,232.499$ & $19,894.703$ & 1.720 \\
\hline 3 & $254,375.192$ & $241,264.205$ & $13,110.987$ & $26,691.120$ & 0.490 \\
\hline 4 & $242,793.009$ & $266,923.332$ & $-24,130.323$ & $42,610.119$ & -0.570 \\
\hline 5 & $266,652.446$ & $225,247.461$ & $41,404.985$ & $31,119.019$ & 1.330 \\
\hline 6 & $232,213.383$ & $261,474.048$ & $-29,260.665$ & $28,219.854$ & -1.040 \\
\hline
\end{tabular}

4.2 Regression analysis: who hires and who gets hired

The marginal effects from logit models with hiring (1) versus non-hiring (0) new ventures as dependent variable are shown in Table 2; the marginal effects are calculated with the remaining explanatory variables set to the mean. Explanatory variables in Model 1 are personal founder characteristics at the time of start-up. Model 2 adds variables related to the year before startup (i.e. labour market status, income, household wealth and entrepreneurship parents), while Model 3 looks at a larger subsample where we have excluded founders that have recruited a family member. An interesting finding is that, of those that hire, we observe that $28 \%$ recruit family members. We suspect that different mechanisms are involved when recruiting family, and we would like to control for this form of recruitment. In Model 4 and Model 5, we run the analysis on a subsample of firms in high-tech and knowledge-intensive business services, because these sectors often attract a large amount of attention, and also because one might argue that these industries have different labour demands in terms of higher "quality", higher skilled employees. All models include region and industry controls (six and 19 dummies, respectively).

Models 1 and 2 show that the likelihood of hiring the first employee is increased by age (at a diminishing rate), education and wealth, although the latter two are only significant on the $10 \%$ level. Moreover, when looking at labour market status the year before startup, founders enrolled in education are more likely to hire $(10 \%$ level), while unemployed founders $(1 \%$ level) and founders outside of the labour market (10\% level) are less likely to hire. This supports the view that education and start-up motivation (i.e. opportunitybased and not necessity-based) are important for attracting the first employee into the firm by signalling personal ability and a promising opportunity. However, in Model 3, where we exclude the subsample of funders that hire family members, we observe some differences. First, the age effect becomes more visible and non-Danish founders are less likely to hire, indicating — interestingly - that if non-Danes hire they are more likely to hire family members. The unemployment variable is still significant, but the marginal effect has decreased. Wealth and enrolment in college 
Table 2 Who hires? Regression results (marginal effects) from logit models with hiring (1) versus non-hiring (0) as dependent variable

\begin{tabular}{|c|c|c|c|c|c|}
\hline & Model $1 \mathrm{mfx}$ & Model $2 \mathrm{mfx}$ & Model $3 \mathrm{mfx}$ & Model $4 \mathrm{mfx}$ & Model $5 \mathrm{mfx}$ \\
\hline \multirow[t]{2}{*}{ Female } & -0.001 & -0.000 & 0.001 & $-0.017 * * *$ & $-0.009 * * *$ \\
\hline & $(0.003)$ & $(0.003)$ & $(0.002)$ & $(0.005)$ & $(0.004)$ \\
\hline \multirow[t]{2}{*}{ Age } & $0.002 * *$ & $0.002 * *$ & $0.004 * * *$ & $0.006 * * *$ & $0.006 * * *$ \\
\hline & $(0.001)$ & $(0.001)$ & $(0.001)$ & $(0.002)$ & $(0.002)$ \\
\hline \multirow[t]{2}{*}{$\mathrm{Age}^{2}$} & $-0.000 * * *$ & $-0.000 * * *$ & $-0.000 * * *$ & $-0.000 * * *$ & $-0.000 * * *$ \\
\hline & $(0.000)$ & $(0.000)$ & $(0.000)$ & $(0.000)$ & $(0.000)$ \\
\hline \multirow[t]{2}{*}{ Non-Danish } & 0.002 & 0.004 & $-0.014 * * *$ & 0.002 & 0.007 \\
\hline & $(0.004)$ & $(0.004)$ & $(0.003)$ & $(0.012)$ & $(0.010)$ \\
\hline \multirow[t]{2}{*}{ Married } & $0.004 *$ & 0.003 & -0.002 & -0.002 & $-0.009 * *$ \\
\hline & $(0.003)$ & $(0.003)$ & $(0.002)$ & $(0.006)$ & $(0.004)$ \\
\hline \multirow[t]{2}{*}{ College degree } & $0.007 *$ & $0.008^{*}$ & $0.006^{*}$ & $0.010^{*}$ & $0.010 * *$ \\
\hline & $(0.004)$ & $(0.004)$ & $(0.004)$ & $(0.006)$ & $(0.004)$ \\
\hline \multirow[t]{2}{*}{ Unemployed } & & $-0.013 * * *$ & $-0.008 * * *$ & $-0.026 * * *$ & $-0.013 * * *$ \\
\hline & & $(0.004)$ & $(0.003)$ & $(0.007)$ & $(0.005)$ \\
\hline \multirow[t]{2}{*}{ Outside labour force } & & $-0.009 *$ & $-0.007 *$ & -0.012 & -0.003 \\
\hline & & $(0.005)$ & $(0.004)$ & $(0.011)$ & $(0.008)$ \\
\hline \multirow[t]{2}{*}{ Enrolled education } & & $0.031 *$ & 0.018 & 0.057 & 0.035 \\
\hline & & $(0.016)$ & $(0.012)$ & $(0.049)$ & $(0.034)$ \\
\hline \multirow[t]{2}{*}{ Previous income (ln) } & & -0.000 & -0.000 & $-0.002 * * *$ & $-0.001 * * *$ \\
\hline & & $(0.000)$ & $(0.000)$ & $(0.001)$ & $(0.000)$ \\
\hline \multirow[t]{2}{*}{ Household wealth (ln) } & & $0.001 *$ & 0.001 & $0.002 *$ & 0.001 \\
\hline & & $(0.000)$ & $(0.000)$ & $(0.001)$ & $(0.001)$ \\
\hline \multirow[t]{2}{*}{ Entrepreneurship parents } & & -0.002 & 0.001 & -0.002 & 0.002 \\
\hline & & $(0.003)$ & $(0.002)$ & $(0.005)$ & $(0.004)$ \\
\hline Log likelihood & -7751.552 & -7639.529 & -5865.682 & -1344.908 & -947.660 \\
\hline Pseudo- $R^{2}$ & 0.048 & 0.049 & 0.066 & 0.033 & 0.062 \\
\hline Observations & 33,266 & 32,904 & 32,291 & 6971 & 6851 \\
\hline Industries & All & All & All & High-tech and KIBS & High-tech and KIBS \\
\hline Industry dummies (19) & Yes & Yes & Yes & Yes & Yes \\
\hline Region dummies (6) & Yes & Yes & Yes & Yes & Yes \\
\hline Includes family hires & Yes & Yes & No & Yes & No \\
\hline
\end{tabular}

Robust standard errors in parentheses

*** $p<0.001 ; * * p<0.01 ; * p<0.05 ;{ }^{+} p<0.1$

become insignificant, when controlling for family members. In Model 4 and Model 5, we turn our attention to new ventures founded in high-tech and knowledge-intensive business services only, and the two models show similar results. When looking only at Model 5, where we removed those that hire family members, we can observe that women and married individuals are less likely to be hired, the age effect is stronger (i.e. likelihood increases with age at a diminishing rate) and higher educated founders are more likely to hire (now significant at the $5 \%$ level). Turning to founder status before start-up, those previously unemployed are again less likely to be hired while, surprisingly, previous income has a negative effect. An explanation of the latter could be that those with a high income before start-up may assess their competences superior to that of potential recruits and for that reason, underestimate the gains to 
hiring a new employee (this may be due to a genuine skills gap or merely a perceived skills gap due to "illusory superiority").

The next question concerns which employees the hiring solo entrepreneurs are able to attract to the venture. Table 3 mirrors the models in Table 2 and shows the regression results from logit models with, as dependent variable, being hired in a new venture (1) versus an established venture (0). Only now, the explanatory variables are employee characteristics instead of founder characteristics. Model 1 and Model 2 show that the likelihood of being recruited in a new venture increases with age (at a diminishing rate) as well as being higher for non-Danes, married and those with entrepreneurial parents. In addition, individuals without a college degree, and with previous low income, are more likely to be hired in a new venture. Finally, workers coming from unemployment or outside of the labour force are more likely to find employment in a new venture compared to an established firm, while the opposite is found for individuals enrolled in education before recruitment. These effects, which can be considered as indicators for individuals that are more marginalized on the labour market, are in line with the theory (Bhide 2000; Parker 2004). Moreover, the finding that individuals with entrepreneurial parents are more likely to work in new ventures could be explained by preference for this type of occupation shaped by the environment in which they were raised. However, Model 3 reveals that this effect disappears when controlling for family hires, suggesting that the children of entrepreneurs being hired in the family firm drive the positive effect in Model 2.

In addition, in Model 3 shows that non-Danish and married workers are not more likely to work for new ventures when excluding family hires, although the negative and positive effects of a college degree and unemployment, respectively, are still strong and significant. Finally, wealthy individuals are less likely to work for a new venture when excluding family hires, and positive and negative effects of being outside of the force and enrolled in education before recruitment, respectively, are significant now only at the $10 \%$ level.

In Models 4 and 5, we direct our focus again to firms in high-tech and knowledge-intensive business services. The results mirror those found in the previous models, although a few differences are worth mentioning. First, females and individuals outside of the labour force are more likely to work in new ventures compared to established ventures when family firms are included (Model 4), but not when they are excluded (Model 5). Second, individuals unemployed before recruitment are more likely to be hired by new ventures compared to established as found before, but the marginal effects are significantly larger in high-tech and knowledge-intensive business services both when including and excluding family hires. Third, individuals with a college degree are surprisingly not significantly less likely to find work in new ventures compared to established firms as found in the previous models including all industries.

Overall, based on these findings we can conclude that established firms are more likely to hire employees with a stronger labour market profile, leaving the more marginalized workers on the labour market to the new firms that struggle to pay high wages and need to convince potential employees of a promising future in the new venture. However, this pattern appears to be different when controlling for family recruitment or focusing solely on high-tech and knowledge-intensive business services. In general, high-income individuals and individuals with a college degree are less likely to be recruited in new ventures, while previously unemployed individuals and non-Danes are more likely to be hired in new ventures. When excluding family recruitment, the effect on non-Danes disappears. The effect of college degree disappears-and the effect of unemployment is amplified-in high-tech and knowledge-intensive business services. The effects of previous income and unemployment are significant in all models.

\subsection{Regression analysis: post-hire profits}

An important research question surrounding the phenomenon of the first hire concerns whether hiring entrepreneurs enjoy superior business-level performance. To investigate this, we run logit regressions to see if the first hire improves business-level performance, while controlling for other possible confounding influences.

The three logit models in Tables 4 and 5 mirror the first three models in Table 1, except for the dependent variable measuring whether the hiring new venture is in the top third, or "tercile" (1), or bottom tercile (0), regarding profits 5 years after start-up (3 years after 
Table 3 Who gets hired? Regression results (marginal effects) from logit models with being hired in a new venture (1) versus an established venture (0) as dependent variable

\begin{tabular}{|c|c|c|c|c|c|}
\hline & Model $1 \mathrm{mfx}$ & Model $2 \mathrm{mfx}$ & Model $3 \mathrm{mfx}$ & Model $4 \mathrm{mfx}$ & Model $5 \mathrm{mfx}$ \\
\hline \multirow[t]{2}{*}{ Female } & $0.011 *$ & 0.009 & -0.005 & $0.048 * * *$ & -0.002 \\
\hline & $(0.006)$ & $(0.006)$ & $(0.005)$ & $(0.017)$ & $(0.014)$ \\
\hline \multirow[t]{2}{*}{ Age } & $0.009 * * *$ & $0.010 * * *$ & $0.009 * * *$ & $0.012 * * *$ & $0.013 * * *$ \\
\hline & $(0.001)$ & $(0.001)$ & $(0.001)$ & $(0.005)$ & $(0.004)$ \\
\hline \multirow[t]{2}{*}{$\mathrm{Age}^{2}$} & $-0.000 * * *$ & $-0.000 * * *$ & $-0.000 * * *$ & $-0.000 * *$ & $-0.000 * * *$ \\
\hline & $(0.000)$ & $(0.000)$ & $(0.000)$ & $(0.000)$ & $(0.000)$ \\
\hline \multirow[t]{2}{*}{ Non-Danish } & $0.089 * * *$ & $0.070 * * *$ & 0.014 & 0.040 & 0.041 \\
\hline & $(0.012)$ & $(0.012)$ & $(0.010)$ & $(0.037)$ & $(0.035)$ \\
\hline \multirow[t]{2}{*}{ Married } & $0.013 *$ & $0.017 * *$ & -0.008 & $0.041 *$ & -0.020 \\
\hline & $(0.007)$ & $(0.007)$ & $(0.006)$ & $(0.022)$ & $(0.017)$ \\
\hline \multirow[t]{2}{*}{ College degree } & -0.011 & $-0.021 * *$ & $-0.019 * * *$ & -0.016 & -0.017 \\
\hline & $(0.008)$ & $(0.008)$ & $(0.007)$ & $(0.020)$ & $(0.016)$ \\
\hline \multirow[t]{2}{*}{ Unemployed } & & $0.025 * *$ & $0.022 * *$ & $0.085^{* *}$ & $0.075 * *$ \\
\hline & & $(0.010)$ & $(0.009)$ & $(0.040)$ & $(0.037)$ \\
\hline \multirow[t]{2}{*}{ Outside labour force } & & $0.038 * * *$ & $0.017 *$ & $0.126 * *$ & 0.053 \\
\hline & & $(0.012)$ & $(0.010)$ & $(0.051)$ & $(0.043)$ \\
\hline \multirow[t]{2}{*}{ Enrolled education } & & $-0.025^{* *}$ & $-0.016^{*}$ & 0.021 & 0.023 \\
\hline & & $(0.010)$ & $(0.009)$ & $(0.042)$ & $(0.036)$ \\
\hline \multirow[t]{2}{*}{ Previous income $(\ln )$} & & $-0.005^{* * *}$ & $-0.003 * * *$ & $-0.009 * * *$ & $-0.005 * *$ \\
\hline & & $(0.001)$ & $(0.001)$ & $(0.002)$ & $(0.002)$ \\
\hline \multirow[t]{2}{*}{ Household wealth (ln) } & & -0.001 & $-0.002 * *$ & 0.001 & -0.002 \\
\hline & & $(0.001)$ & $(0.001)$ & $(0.004)$ & $(0.003)$ \\
\hline \multirow[t]{2}{*}{ Entrepreneurship parents } & & $0.013 * *$ & 0.003 & 0.008 & 0.010 \\
\hline & & $(0.006)$ & $(0.005)$ & $(0.019)$ & $(0.016)$ \\
\hline Log likelihood & -5102.258 & -4903.166 & -3872.154 & -762.027 & -571.074 \\
\hline Pseudo- $R^{2}$ & 0.091 & 0.104 & 0.100 & 0.112 & 0.099 \\
\hline Observations & 13,927 & 13,555 & 12,999 & 1849 & 1732 \\
\hline Industries & All & All & All & High-tech and KIBS & High-tech and KIBS \\
\hline Industry dummies (19) & Yes & Yes & Yes & Yes & Yes \\
\hline Region dummies (6) & Yes & Yes & Yes & Yes & Yes \\
\hline
\end{tabular}

Robust standard errors in parentheses

*** $p<0.001 ; * * p<0.01 ; * p<0.05 ;^{+} p<0.1$

hiring). Table 4 includes founder characteristics, while Table 5 includes employee characteristics.

Table 4 reveals that high post-hire profits are associated with founders with a college degree and founders that had a relatively high income in the year prior to founding. Overall, not only is a strong founder profile important for attracting the first employee, but it is also important for the subsequent chance of high profits. This could be due to more talented founders being able to attract better employees, which is supported by Dahl and Klepper (2016) and Bublitz et al. (2015). In addition, male founders are more likely to enjoy high post-hire profits.

Interestingly, when looking at employee characteristics in Table 5, these are largely unable to explain the performance of the new venture, besides a positive effect of previous income when including family hires (Model 2) and a positive effect of having a college degree when excluding family hires (Model 3 ). Thus, the employee characteristics as such seem not to be of vital importance for the performance of the new venture after hiring. This makes sense, considering 
Table 4 Regression results (marginal effects) - who hires and subsequent performance (top tercile of treatment, in terms of profits, versus bottom tercile of treatment)
Robust standard errors in parentheses

$* * * p<0.001$;

$* * p<0.01$; * $p<0.05$,

$+p<0.1$

\begin{tabular}{|c|c|c|c|}
\hline & Model $1 \mathrm{mfx}$ & Model $2 \mathrm{mfx}$ & Model $3 \mathrm{mfx}$ \\
\hline Female & $\begin{array}{c}-0.131 * * * \\
(0.046)\end{array}$ & $\begin{array}{c}-0.126 * * * \\
(0.048)\end{array}$ & $\begin{array}{c}-0.147 * * \\
(0.060)\end{array}$ \\
\hline Age & $\begin{array}{c}0.015 \\
(0.012)\end{array}$ & $\begin{array}{c}0.016 \\
(0.013)\end{array}$ & $\begin{array}{c}0.018 \\
(0.019)\end{array}$ \\
\hline $\mathrm{Age}^{2}$ & $\begin{array}{r}-0.000 \\
(0.000)\end{array}$ & $\begin{array}{r}-0.000 \\
(0.000)\end{array}$ & $\begin{array}{r}-0.000 \\
(0.000)\end{array}$ \\
\hline Non-Danish & $\begin{array}{r}-0.038 \\
(0.061)\end{array}$ & $\begin{array}{r}-0.033 \\
(0.066)\end{array}$ & $\begin{array}{c}0.001 \\
(0.106)\end{array}$ \\
\hline Married & $\begin{array}{r}-0.029 \\
(0.037)\end{array}$ & $\begin{array}{r}-0.026 \\
(0.038)\end{array}$ & $\begin{array}{r}-0.012 \\
(0.046)\end{array}$ \\
\hline College degree & $\begin{array}{c}0.103 * \\
(0.055)\end{array}$ & $\begin{array}{c}0.095^{*} \\
(0.057)\end{array}$ & $\begin{array}{l}0.160 * * \\
(0.070)\end{array}$ \\
\hline Unemployed & & $\begin{array}{r}-0.003 \\
(0.080)\end{array}$ & $\begin{array}{c}0.035 \\
(0.091)\end{array}$ \\
\hline Outside labour force & & $\begin{array}{c}0.097 \\
(0.098)\end{array}$ & $\begin{array}{c}0.091 \\
(0.130)\end{array}$ \\
\hline Enrolled education & & $\begin{array}{c}0.103 \\
(0.161)\end{array}$ & $\begin{array}{r}-0.069 \\
(0.219)\end{array}$ \\
\hline Previous income (ln) & & $\begin{array}{l}0.015^{* * *} \\
(0.004)\end{array}$ & $\begin{array}{l}0.014 * * * \\
(0.005)\end{array}$ \\
\hline Household wealth (ln) & & $\begin{array}{r}-0.003 \\
(0.008)\end{array}$ & $\begin{array}{r}-0.002 \\
(0.009)\end{array}$ \\
\hline Entrepreneurship parents & & $\begin{array}{r}-0.032 \\
(0.037)\end{array}$ & $\begin{array}{r}-0.013 \\
(0.042)\end{array}$ \\
\hline Log likelihood & -655.914 & -640.868 & -446.241 \\
\hline Pseudo- $R^{2}$ & 0.036 & 0.047 & 0.049 \\
\hline Observations & 982 & 970 & 677 \\
\hline Industries & All & All & All \\
\hline Industry dummies (19) & Yes & Yes & Yes \\
\hline Region dummies (6) & Yes & Yes & Yes \\
\hline Includes family hires & Yes & Yes & No \\
\hline
\end{tabular}

that explain which institutional-level (Carroll et al. 2000; Mathur 2010; Millan et al. 2013) and entrepreneur-level (Burke et al. 2000, 2001; Cowling et al. 2004; Henley 2005; Andersson and Wadensjo 2007; Congregado et al. 2010) characteristics turn solo entrepreneurs into employers, we contribute by investigating the effect of hiring on new venture performance and also include a detailed analysis of who gets hired, besides anecdotal evidence that points to a necessity-based approach of entrepreneurship employment, i.e. individuals that are marginalized on the labour market. In this paper, we analyse a rich and unique dataset on Danish new ventures to provide clean evidence on the circumstances surrounding the 
Table 5 Regression results (marginal effects) - who gets hired and subsequent performance (top tercile of treatment, in terms of profits, versus bottom tercile of treatment)
Robust standard errors in parentheses

$* * * p<0.001$

** $p<0.01$; * $p<0.05$;

$+p<0.1$

\begin{tabular}{|c|c|c|c|}
\hline & Model $1 \mathrm{mfx}$ & Model $2 \mathrm{mfx}$ & Model $3 \mathrm{mfx}$ \\
\hline \multirow[t]{2}{*}{ Female } & 0.012 & 0.022 & 0.024 \\
\hline & $(0.038)$ & $(0.039)$ & $(0.048)$ \\
\hline \multirow[t]{2}{*}{ Age } & -0.003 & -0.007 & 0.001 \\
\hline & $(0.007)$ & $(0.008)$ & $(0.010)$ \\
\hline \multirow[t]{2}{*}{$\mathrm{Age}^{2}$} & -0.000 & 0.000 & -0.000 \\
\hline & $(0.000)$ & $(0.000)$ & $(0.000)$ \\
\hline \multirow[t]{2}{*}{ Non-Danish } & -0.073 & -0.058 & -0.049 \\
\hline & $(0.055)$ & $(0.060)$ & $(0.084)$ \\
\hline \multirow[t]{2}{*}{ Married } & -0.019 & -0.030 & 0.003 \\
\hline & $(0.040)$ & $(0.043)$ & $(0.051)$ \\
\hline \multirow[t]{2}{*}{ College degree } & 0.062 & 0.064 & $0.149 * *$ \\
\hline & $(0.056)$ & $(0.062)$ & $(0.076)$ \\
\hline \multirow[t]{2}{*}{ Unemployed } & & 0.054 & 0.005 \\
\hline & & $(0.055)$ & $(0.067)$ \\
\hline \multirow[t]{2}{*}{ Outside labour force } & & -0.008 & -0.119 \\
\hline & & $(0.067)$ & $(0.087)$ \\
\hline \multirow[t]{2}{*}{ Enrolled education } & & -0.020 & -0.005 \\
\hline & & $(0.090)$ & $(0.106)$ \\
\hline \multirow[t]{2}{*}{ Previous income (ln) } & & $0.011 * *$ & 0.007 \\
\hline & & $(0.005)$ & $(0.006)$ \\
\hline \multirow[t]{2}{*}{ Household wealth (ln) } & & 0.004 & 0.001 \\
\hline & & $(0.006)$ & $(0.006)$ \\
\hline \multirow[t]{2}{*}{ Entrepreneurship parents } & & -0.053 & -0.050 \\
\hline & & $(0.038)$ & $(0.045)$ \\
\hline Log likelihood & -659.360 & -637.282 & -444.568 \\
\hline Pseudo- $R^{2}$ & 0.031 & 0.040 & 0.038 \\
\hline Observations & 982 & 958 & 667 \\
\hline Industries & All & All & All \\
\hline Industry dummies (19) & Yes & Yes & Yes \\
\hline Region dummies (6) & Yes & Yes & Yes \\
\hline Includes family hires & Yes & Yes & No \\
\hline
\end{tabular}

first hire. Entrepreneurs that hire 2 years after founding were observed to enjoy superior sales in the previous year, suggesting that sales growth precedes the first hire. Regression analysis of the first hire event highlighted the expected selection of variables when looking at the personal characteristics of founders that hire and employees that get hired. More educated founders with employment before founding the venture-making necessity start-up less likely—are more likely to hire the first employee, which is in line with previous research on hiring decisions of entrepreneurs (Burke et al. 2000, 2001; Cowling et al. 2004). Those that get hired could be characterized as being more marginalized on the labour market (compared to those that get hired in established firms), lining up on the expectations put forward by Bhide (2000) and Parker (2004). That is, they are less educated and having been unemployed or employed with a low income before being hired. Solo entrepreneurs that take on their first employee experience higher sales growth, while the dispersion in profits increases. As expected, stronger founders are more likely to achieve high profits, while the employee characteristics are less important. This has important policy implications, as eliminating the barriers for hiring the first employee benefits not only the entrepreneur, but also society, because individuals hired may have a marginal status on labour markets. Moreover, these findings add to the discussion 
regarding whether policy should focus on promoting new venture creation in general, or target certain individuals with a strong entrepreneurial profile.

Our analysis is not without limitations. First, the Danish context should be taken into account. Although there are many similarities between the labour market in Denmark and other developed countries such as the USA (see, for example, Bingley and WestergaardNielsen (2003) who write that the Danish and US labour markets are about equally fluid), the unemployment benefits are more generous than in many other developed countries, which could result in fewer necessity-based entrepreneurs and marginalized employees. Nevertheless, the start-up rate in Denmark is not significantly different than in advanced economies with other levels of unemployment benefits and the survival rate of new firms in Denmark-where about one half are closed within the first 3 years-is similar to findings in other advanced economies (e.g. Coad et al. 2013; Anyadike-Danes and Hart 2014). Second, we have no information on the relationship between the founder and the first employee (e.g. from the social network) or information on informal help in the new firm from friends and family. This could be an important issue, however. Research in social psychology has shown that individuals show self-related biases when the comparison other is a vague case such as "most others" or "the average other", but selfrelated biases are attenuated or removed when the other is a familiar person such as a best same-sex friend or a sibling (Hoorens 1993, p. 122). This indicates that the characteristics of the first hire, and their relationship to the entrepreneur, may moderate the entrepreneur's "illusory superiority" regarding the first hire. Another consideration to be borne in mind is that the phenomenon of illusory superiority may no longer hold when the hiring team consists of more than one individual, because of other social psychological phenomena such as focalism and group diffuseness may play a role and even neutralize any egocentric “illusory superiority" effect (Krizan and Suls 2008). Furthermore, entrepreneurs will differ in their degree of overconfidence (Forbes 2005). In addition, there may be unobserved variables, e.g. relating to the characteristics and traits of the entrepreneur and the employee, that might have an influence.

Other possible limitations concern our empirical methodology. The complexities of the timing and circumstances of the first hire led us to narrow down on a methodological set-up with strict conditions-we distinguished between those who hired one individual 2 years after founding, and those that hired no one 2 years after founding (see Fig. 1). These strict conditions could be explored in further work. For example, discrete time duration models could be applied to investigate the duration between the business founding and the first hire. Further work could also investigate the characteristics of entrepreneurs (and their employees) where the hire occurred after more than 2 years, or in cases where two or more employees were hired instead of just one.

Overall, we have sought to respond to repeated calls for an improved understanding into the characteristics and determinants of firm growth (Gilbert et al. 2006; Coad 2009; McKelvie and Wiklund 2010) by suggesting that a better understanding of the growth of new ventures can be achieved by focusing on the "microfoundations" of growth. In particular, we focus on the first hire made by solo self-employed entrepreneurs, which corresponds to the first and perhaps the biggest growth hurdle a growing firm will face. A detailed analysis of other "trigger points" (Brown and Mawson 2013) in the growth process, such as the discrete events of opening a new plant, diversifying into an unknown market or entering a new export market, might also provide valuable insights into the complexities of firm growth and the potential benefits for the entrepreneurs, the employees and the society.

\section{Conclusion}

We investigated the phenomenon of the first hire using a rich dataset on new Danish businesses and tracked the performance over time of entrepreneurs who hire one employee (compared to those who do not). Entrepreneurs making their first hire enjoyed higher sales growth in the previous year, suggesting that sales growth precedes employment growth in these new businesses. This suggests that not all new businesses should seek to hire, but only those new businesses that have sufficient growth in sales to justify the need for new employees. New businesses that aggressively seek to expand by hiring new employees, without first experiencing an increase in sales, may therefore run into difficulties. Our results therefore shed light on how ambitious new businesses should embark on growth trajectories. 
Regressions shed light on the characteristics of the entrepreneurs and individuals who participate in the first hire decision. Entrepreneurs who hire are more educated and were employed before founding the new business (hence, are not "necessity entrepreneurs"). Individuals hired into these businesses are relatively marginalized on labour markets, which underscores that the jobs created by new businesses play an important social role in providing jobs to neglected strata in society.

Acknowledgments The views expressed are purely those of the authors and may not in any circumstances be regarded as stating an official position of the European Commission. We are grateful to Robert Axtell, Sven-Olov Daunfeldt, Weixi Liu, Erik Monsen, Gabriele Pellegrino, Jose Garcia Quevedo, Johan Wiklund, Haibo Zhou and seminar participants at Oxford University (UK), Universitat de Barcelona (E), BCERC 2014 (London, ON, Canada) and AoM 2014 (Philadelphia, USA).
A.C. gratefully acknowledges financial support from the ESRC, TSB, BIS and NESTA on Grants ES/H008705/1 and ES/ J008427/1 as part of the IRC distributed projects initiative, as well as from the AHRC as part of the FUSE project. The usual caveat applies.

Open Access This article is distributed under the terms of the Creative Commons Attribution 4.0 International License (http:// creativecommons.org/licenses/by/4.0/), which permits unrestricted use, distribution, and reproduction in any medium, provided you give appropriate credit to the original author(s) and the source, provide a link to the Creative Commons license, and indicate if changes were made.

\section{Appendix: Summary statistics and correlations}

See Fig. 3 and Tables 6, 7, 8 and 9.

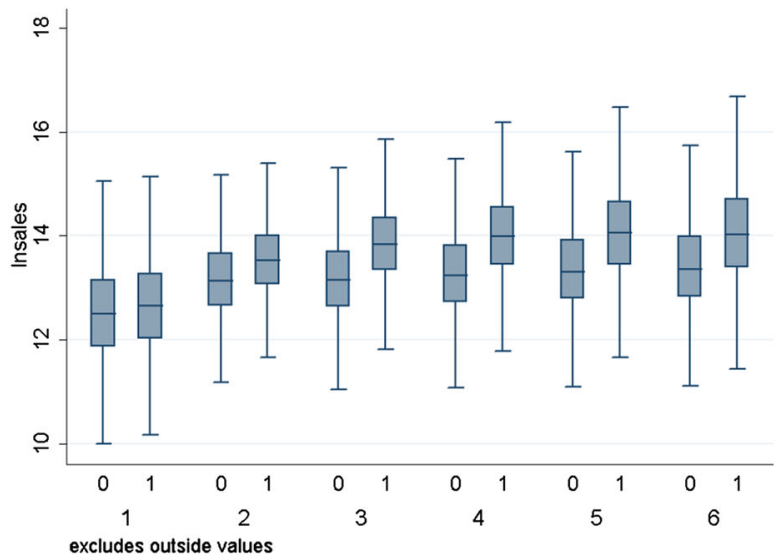

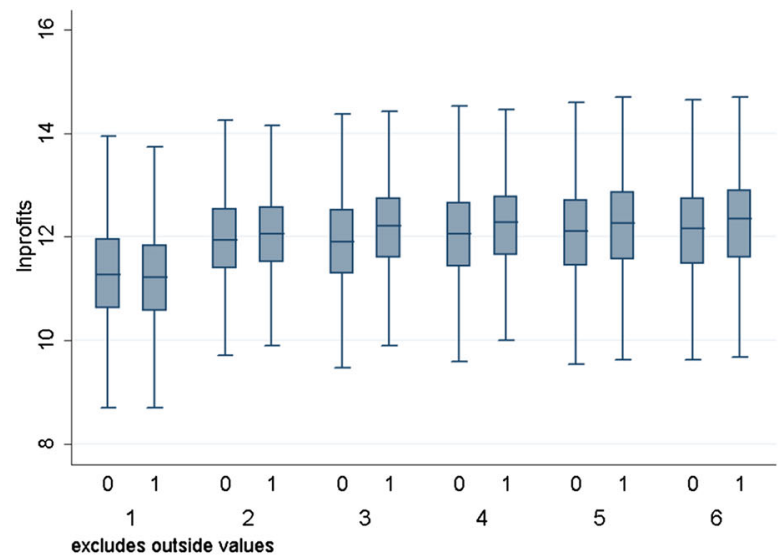

Fig. 3 Boxplots where the variables are log-transformed; i.e. boxplots for the evolution of $\ln (\mathrm{sales}$ ) (left) and $\ln$ (profits) (right), for the 6 years since start-up, for treatment (1) and control (0)

Table 6 Summary statistics (the treatment and control group)

\begin{tabular}{llrr}
\hline Variable & Obs. & \multicolumn{1}{l}{ Mean } & SD \\
\hline Sales & 32,502 & $615,768.000$ & $3,462,816.000$ \\
Profits & 28,473 & $243,159.700$ & $1,443,957.000$ \\
Female & 33,297 & 0.246 & 0.431 \\
Age & 33,297 & 38.931 & 10.425 \\
Non-Danish & 33,292 & 0.091 & 0.287 \\
Married & 33,284 & 0.556 & 0.497 \\
College degree & 33,297 & 0.125 & 0.331 \\
Unemployed & 33,297 & 0.083 & 0.276 \\
Outside labour force & 33,297 & 0.044 & 0.206 \\
In education & 33,297 & 0.009 & 0.094 \\
Previous income & 32,930 & $250,432.500$ & $243,923.000$ \\
\hline
\end{tabular}


Table 6 continued

Table 7 Summary statistics (treatment only)

\begin{tabular}{lrrr}
\hline Variable & Obs. & \multicolumn{1}{c}{ Mean } & \multicolumn{1}{c}{ SD } \\
\hline Household wealth & 32,931 & $1,504,268.000$ & $4,168,580.000$ \\
Entrepreneurship parents & 33,297 & 0.353 & 0.478 \\
Hires family members & 2215 & 0.283 & 0.451 \\
\hline
\end{tabular}

\begin{tabular}{|c|c|c|c|}
\hline Variable & Obs. & Mean & SD \\
\hline Sales & 2190 & $575,980.800$ & $1,331,654.000$ \\
\hline Profits & 2037 & $128,622.000$ & $283,531.000$ \\
\hline Female & 2215 & 0.222 & 0.416 \\
\hline Age & 2215 & 36.372 & 9.190 \\
\hline Non-Danish & 2215 & 0.120 & 0.325 \\
\hline Married & 2215 & 0.537 & 0.499 \\
\hline College degree & 2215 & 0.104 & 0.305 \\
\hline Unemployed & 2215 & 0.074 & 0.261 \\
\hline Outside labour force & 2215 & 0.041 & 0.197 \\
\hline In education & 2215 & 0.013 & 0.114 \\
\hline Previous income & 2184 & $238,810.200$ & $210,415.700$ \\
\hline Household wealth & 2184 & $1,066,746.000$ & $1,750,326.000$ \\
\hline Entrepreneurship parents & 2215 & 0.369 & 0.483 \\
\hline Hires family members & 2215 & 0.283 & 0.451 \\
\hline
\end{tabular}

Table 8 Summary statistics (controls only)

\begin{tabular}{llrr}
\hline Variable & Obs. & \multicolumn{2}{r}{ Mean } \\
\hline Sales & 30,312 & 618642.600 & $3,567,811.000$ \\
Profits & 26,436 & $251,985.300$ & $1,496,127.000$ \\
Female & 31,082 & 0.248 & 0.432 \\
Age & 31,082 & 39.113 & 10.484 \\
Non-Danish & 31,077 & 0.089 & 0.284 \\
Married & 31,069 & 0.558 & 0.497 \\
College degree & 31,082 & 0.127 & 0.333 \\
Unemployed & 31,082 & 0.084 & 0.277 \\
Outside labour force & 31,082 & 0.045 & 0.206 \\
In education & 31,082 & 0.009 & 0.092 \\
Previous income & 30,746 & $251,258.100$ & $246,111.800$ \\
Household wealth & 30,747 & $1,535,346.000$ & $4,287,112.000$ \\
Entrepreneurship parents & 31,082 & 0.351 & 0.477 \\
\hline
\end{tabular}




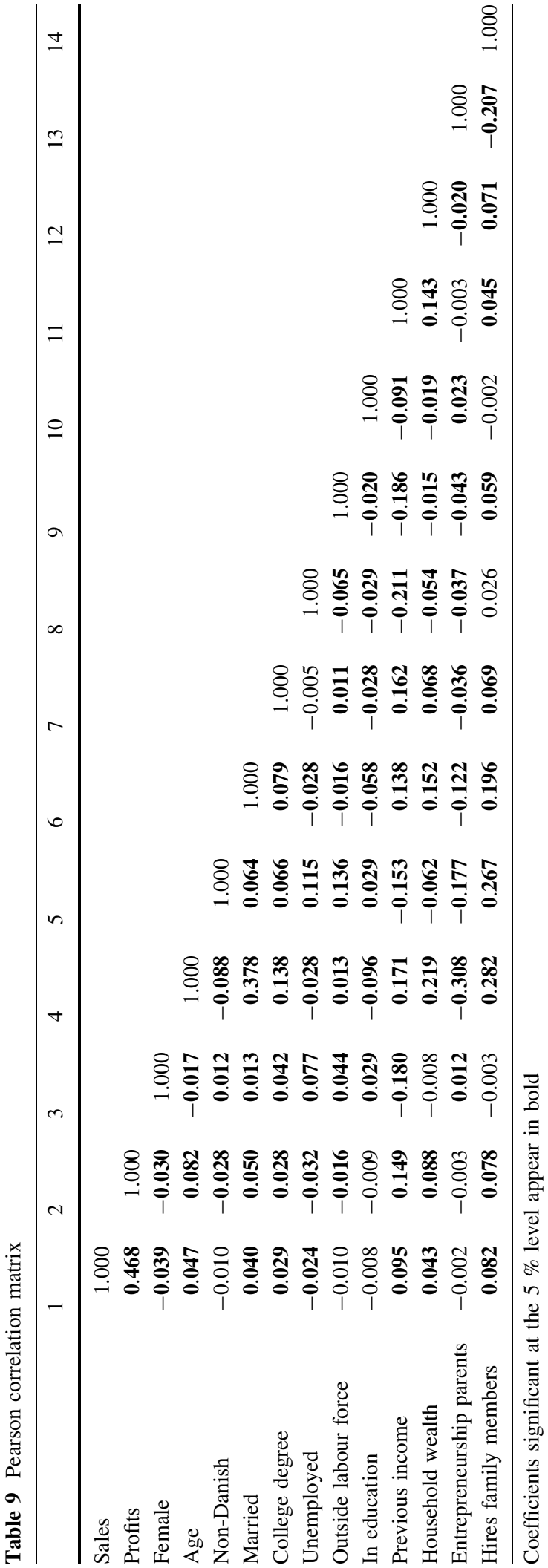

\section{References}

Abadie, A., Drukker, D., Herr, J. L., \& Imbens, G. W. (2004). Implementing matching estimators for average treatment effects in Stata. Stata Journal, 4(3), 290-311.

Achtenhagen, L., Naldi, L., \& Melin, L. (2010). "Business growth"-Do practitioners and scholars really talk about the same thing? Entrepreneurship Theory and Practice, 34(2), 289-316.

Aldrich, H., \& Auster, E. R. (1986). Even dwarfs started small: Liabilities of age and size and their strategic implications. In B. Staw \& L. Cummings (Eds.), Research in organizational behavior (Vol. 8, pp. 165-186). Greenwich, CT: JAI Press.

Aldrich, H. E., \& Ruef, M. (2006). Organizations evolving. Thousand Oaks: Sage.

Andersson, P., \& Wadensjo, E. (2007). Do the unemployed become successful entrepreneurs? International Journal of Manpower, 28(7), 604-626.

Anyadike-Danes, M., \& Hart, M. (2014). All grown up? The fate after 15 years of the quarter of a million UK firms born in 1998. In ISBE conference, Manchester (Vol. 5, No. 6).

Atkinson, J., \& Storey, D. J. (Eds.). (1994). Employment, the small firm, and the labour market. Cengage Learning EMEA.

Barber, A. E., Wesson, M. J., Roberson, Q. M., \& Taylor, M. S. (1999). A tale of two job markets: Organizational size and its effects on hiring practices and job search behavior. Personnel Psychology, 52(4), 841-868.

Barrett, R., \& Mayson, S. (2008). The formality and informality of HRM practices in small firms. In International handbook of entrepreneurship and HRM (pp. 111-136).

Bhide, A. (2000). The origin and evolution of new businesses. Oxford: Oxford University Press.

Bingley, P., \& Westergaard-Nielsen, N. (2003). Returns to tenure, firm-specific human capital and worker heterogeneity. International Journal of Manpower, 24(7), 774-788.

Birch, D. L. (1979). The job generation process. MIT program on neighborhood and regional change. Cambridge, MA: Massachusetts Institute of Technology.

Blanchflower, D. G. (2004). Self-employment: More may not be better. Swedish Economic Policy Review, 11(2004), 15-73.

Boomsma, D., Busjahn, A., \& Peltonen, L. (2002). Classical twin studies and beyond. Nature Reviews Genetics, 3, 872-882.

Brown, R., \& Mawson, S. (2013). Trigger points and highgrowth firms. Journal of Small Business and Enterprise Development, 20(2), 279-295.

Bublitz, E., Nielsen, K., Noseleit, F., \& Timmermans, B. (2015). Entrepreneurship, human capital, and labor demand: A story of signaling and matching. doi:10.2139/ssrn. 2638236. http://ssrn.com/abstract=2638236.

Burke, A. E., FitzRoy, F. R., \& Nolan, M. A. (2000). When less is more: Distinguishing between entrepreneurial choice and performance. Oxford Bulletin of Economics and Statistics, 62(5), 565-587.

Burke, A. E., Fitzroy, F. R., \& Nolan, M. A. (2002). Self-employment wealth and job creation: The roles of gender, non-pecuniary motivation and entrepreneurial ability. Small Business Economics, 19, 255-270. 
Camerer, C., \& Lovallo, D. (1999). Overconfidence and excess entry: An experimental approach. American Economic Review, 89(1), 306-318.

Cardon, M. S., \& Stevens, C. E. (2004). Managing human resources in small organizations: What do we know? $\mathrm{Hu}$ man Resource Management Review, 14(3), 295-323.

Cardon, M. S., \& Tarique, I. (2008). 17 organizational attractiveness of small businesses. In International handbook of entrepreneurship and HRM, p. 345.

Carroll, R., Holtz-Eakin, D., Rider, M., \& Rosen, H. S. (2000). Income taxes and entrepreneurs' use of labor. Journal of Labor Economics, 18(2), 324-351.

Carroll, M., Marchington, M., Earnshaw, J., \& Taylor, S. (1999). Recruitment in small firms: Processes, methods and problems. Employee Relations, 21(3), 236-250.

Coad, A. (2009). The growth of firms: A survey of theories and empirical evidence. Cheltenham and Northampton, MA: Edward Elgar.

Coad, A. (2010). Exploring the processes of firm growth: Evidence from a vector autoregression. Industrial and Corporate Change, 19(6), 1677-1703.

Coad, A., Frankish, J. S., Nightingale, P., \& Roberts, R. G. (2014). Business experience and start-up size: Buying more lottery tickets next time around? Small Business Economics, 43(3), 529-547.

Coad, A., Frankish, J., Roberts, R., \& Storey, D. (2013). Growth paths and survival chances: An application of Gambler's Ruin theory. Journal of Business Venturing, 28, 615-632.

Coad, A., \& Guenther, C. (2014). Processes of firm growth and diversification: Theory and evidence. Small Business Economics, 43, 857-871.

Coad, A., \& Timmermans, B. (2014). Two's company: Composition, structure and performance of entrepreneurial pairs. European Management Review, 11(2), 117-138.

Congregado, E., Millan, J. M., \& Roman, C. (2010). From ownaccount worker to job creator. International Review of Entrepreneurship, 8(4), 277-302.

Cowling, M., Taylor, M., \& Mitchell, P. (2004). Job creators. Manchester School, 72(5), 601-617.

Dahl, M. S., \& Klepper S., (2015). Whom do new firms hire?. Industrial and corporate change, 24(4), 819-836.

Dahl, M. S., \& Sorenson, O. (2012). Home sweet home: Entrepreneurs' location choices and the performance of their ventures. Management Science, 58(6), 1059-1071.

Delmar, F., \& Wiklund, J. (2008). The effect of small business managers' growth motivation on firm growth: A longitudinal study. Entrepreneurship Theory and Practice, 32(3), 437-457.

Denrell J., Fang C., \& Liu C., (2014). Perspective-Chance explanations in the management sciences. Organization Science, 26(3), 923-940.

Deshpande, S. P., \& Golhar, D. Y. (1994). HRM practices in large and small manufacturing firms: A comparative study. Journal of Small Business Management, 32(2), 49.

Forbes, D. P. (2005). Are some entrepreneurs more overconfident than others? Journal of Business Venturing, 20, 623-640.

Freeman, J., Carroll, G. R., \& Hannan, M. T. (1983). The liability of newness: Age dependence in organizational death rates. American Sociological Review, 692-710.

Gartner, W. B. (1997). When growth is the problem, not the solution: An interview with Earl Eisenberg. Journal of Management Inquiry, 6(1), 62-68.
Geroski, P. A. (2000). The growth of firms in theory and in practice. In N. Foss \& V. Mahnke (Eds.), Competence, governance and entrepreneurship (pp. 168-186). Oxford: Oxford University Press.

Gilbert, B. A., McDougall, P. P., \& Audretsch, D. B. (2006). New venture growth: A review and extension. Journal of Management, 32(6), 926-950.

Haltiwanger, J., Jarmin, R. S., \& Miranda, J. (2013). Who creates jobs? Small versus large versus young. Review of Economics and Statistics, 95(2), 347-361.

Hayward, M. L. A., Shepherd, D. A., \& Griffin, D. (2006). A hubris theory of entrepreneurship. Management Science, 52(2), 160-172.

Henley, A. (2005). Job creation by the self-employed: The roles of entrepreneurial and financial capital. Small Business Economics, 25, 175-196.

Ho, D., Imai, K., King, G., \& Stuart, E. A. (2007). Matching as non-parametric preprocessing for reducing model dependence in parametric causal inference. Political Analysis, 15, 199-236.

Hoorens, V. (1993). Self-enhancement and superiority biases in social comparison. European Review of Social Psychology, 4(1), 113-139.

Hornsby, J. S., \& Kuratko, D. F. (1990). Human resource management in small business: Critical issues for the 1990s. Journal of Small Business Management, 28(3), 9.

Imbens, G. W., \& Wooldridge, J. M. (2009). Recent developments in the econometrics of program evaluation. Journal of Economic Literature, 47(1), 5-86.

Katz, J. A., Aldrich, H. E., Welbourne, T. M., \& Williams, P. M. (2000). Guest editor's comments special issue on human resource management and the SME: Toward a new synthesis. Entrepreneurship: Theory and Practice, 25(1), 7-7.

Krizan, Z., \& Suls, J. (2008). Losing sight of oneself in the above-average effect: When egocentrism, focalism, and group diffuseness collide. Journal of Experimental Social Psychology, 44, 929-942.

Lee, N. (2014). What holds back high-growth firms? Evidence from UK SMEs. Small Business Economics, 43(1), 183-195.

Leung, A. (2003). Different ties for different needs: Recruitment practices of entrepreneurial firms at different developmental phases. Human Resource Management, 42(4), 303-320.

Leung, A., Zhang, J., Wong, P. K., \& Der Foo, M. (2006). The use of networks in human resource acquisition for entrepreneurial firms: Multiple "fit" considerations. Journal of Business Venturing, 21(5), 664-686.

Leuven, E., \& Sianesi, B. (2003). PSMATCH2: Stata module to perform full Mahalanobis and propensity score matching, common support graphing, and covariate imbalance testing. http://ideas.repec.org/c/boc/bocode/s432001.html (Accessed December 21, 2011).

Mathur, A. (2010). Health insurance and job creation by the selfemployed. Small Business Economics, 35(3), 299-317.

McKelvie, A., \& Wiklund, J. (2010). Advancing firm growth research: A focus on growth mode instead of growth rate. Entrepreneurship Theory and Practice, 34(2), 261-288.

Millan, A., Millan, J.-M., Roman, C., \& van Stel, A. (2013). How does employment protection legislation influence hiring and firing decisions by the smallest firms? Economics Letters, 121, 444-448. 
Miller, C. C., Washburn, N. T., \& Glick, W. H. (2013). The myth of firm performance. Organization Science, 24(3), 948-964.

Moneta, A., Entner, D., Hoyer, P., \& Coad, A. (2013). Causal Inference by independent component analysis: Theory and applications. Oxford Bulletin of Economics and Statistics, 75(5), 705-730.

Nanda, R., \& Sørensen, J. B. (2010). Workplace peers and entrepreneurship. Management Science, 56(7), 11161126.

Nielsen, K. (2015). Human capital and new venture performance: The industry choice and performance of academic entrepreneurs. The Journal of Technology Transfer, 40(3), 453-474.

Parker, S. C. (2004). The economics of self-employment and entrepreneurship. Cambridge: Cambridge University Press.

Penrose, E. T. (1959). The theory of the growth of the firm. Oxford: Basil Blackwell.

Sand, A., \& Paaske, H. (2010). Har du råd til en ansat? Ivarksatteren, $51,10$.

Sarasvathy, S. D. (2004). The questions we ask and the questions we care about: Reformulating some problems in entrepreneurship research. Journal of Business Venturing, 19(5), 707-717.

Sarasvathy, S. D. (2008). Effectuation-Elements of entrepreneurial expertise. Cheltenham: Edward Elgar.
Sexton, D. L., \& Smilor, R. W. (1997). Growth strategies. In D. L. Sexton \& R. W. Smilor (Eds.), Entrepreneurship 2000 (pp. 97-98). Chicago, IL: Upstart.

Shane, S. A. (2003). A general theory of entrepreneurship: The individual-opportunity nexus. Northampton, MA: Edward Elgar.

Shepherd, D., \& Wiklund, J. (2009). Are we comparing apples with apples or apples with oranges? Appropriateness of knowledge accumulation across growth studies. Entrepreneurship Theory and Practice, 33(1), 105-123.

Simon, H. A. (1984). On the behavioral and rational foundations of economic dynamics. Journal of Economic Behavior \& Organization, 5, 35-55.

Stinchcombe, A. (1965). Social structure and organizations. In J. G March (Ed.), Handbook of organizations (Chapt. 4, pp. 142-193). Chicago: Rand McNally.

Tamvada, J. P. (2010). Entrepreneurship and welfare. Small Business Economics, 34, 65-79.

Timmermans, B. (2010). The Danish integrated database for labor market research: Towards demystification for the English speaking audience (DRUID Working Paper).

Williamson, I. O., Cable, D. M., \& Aldrich, H. E. (2002). Smaller but not necessarily weaker: How small businesses can overcome barriers to recruitment. In J. A. Katz, T. M. Welbourne (Eds.), Advances in Entrepreneurship, Firm Emergence and Growth (vol. 5, pp. 83-106). 